\title{
Intramammary lipopolysaccharide infusion induces local and systemic effects on milk components in lactating bovine mammary glands
}

\author{
E. M. Shangraw, ${ }^{1} \oplus$ R. O. Rodrigues,,${ }^{1} \oplus$ M. C. Witzke, ${ }^{2}$ ๑ R. K. Choudhary, ${ }^{3}$ F.-Q. Zhao, ${ }^{3}{ }^{\circ}$ \\ and T. B. McFadden ${ }^{1 *}$ (1) \\ ${ }^{1}$ Division of Animal Sciences, University of Missouri, Columbia 65211 \\ ${ }^{2}$ Department of Veterinary Medicine and Surgery, University of Missouri, Columbia 65211 \\ ${ }^{3}$ Department of Animal and Veterinary Sciences, University of Vermont, Burlington 05405
}

\section{ABSTRACT}

Each quarter of the bovine mammary gland is an anatomically and functionally distinct gland. However, mastitis in one quarter may affect function of adjacent, uninfected glands. To investigate the mechanisms and potential mediators of these effects, we quantified early responses of the mammary gland to intramammary lipopolysaccharide (LPS) challenge, distinguishing between local and systemic effects. Ten multiparous cows over $70 \mathrm{~d}$ in milk were blocked into pairs by breed, cowlevel somatic cell count (SCC), and milk yield. Within block, one cow was assigned to LPS treatment (T) such that both the front and the rear quarter of a randomly selected udder half received an infusion of $50 \mu \mathrm{g}$ of LPS in $10 \mathrm{~mL}$ of saline (T-L); the contralateral quarters received only $10 \mathrm{~mL}$ of saline (T-S). Similarly, each paired control cow $(\mathrm{C})$ received either $10 \mathrm{~mL}$ of saline (C-S) or no infusion (C-N) into udder halves. Cows were quarter milked twice daily, with foremilk samples ( $\sim 30 \mathrm{~mL}$, front quarters) taken at $-24,0,3,6,12$, and $24 \mathrm{~h}$ relative to infusions. At $24 \mathrm{~h}$, average milk yield in T-L and T-S quarters fell to 23 and $32 \%$ of pre-infusion levels, respectively. For $\mathrm{T}$ cows, systemic effects were observed by $3 \mathrm{~h}$ post-infusion as rectal temperature was elevated and foremilk fat concentration was reduced in both T-L and T-S. However, SCC and concentrations of L-lactate and total protein in foremilk indicated a local response to LPS: protein was transiently higher at $3 \mathrm{~h}$, whereas SCC and lactate were higher at $6 \mathrm{~h}$ in T-L compared with T-S. Lactose concentration showed a local effect at $6 \mathrm{~h}$, being lower in T-L than in T-S, and then a systemic effect at $12 \mathrm{~h}$, being lower in both T-L and $\mathrm{T}-\mathrm{S}$ than $\mathrm{C}$ quarters. Concomitant with changes in milk, systemic effects were also observed in blood.

Received December 7, 2019.

Accepted March 18, 2020.

*Corresponding author: mcfaddent@missouri.edu
Plasma antioxidant potential and glucose concentration were lower in $\mathrm{T}$ cows than in $\mathrm{C}$ cows at 6 or $12 \mathrm{~h}$, respectively, although neither variable remained different at $24 \mathrm{~h}$. In summary, unilateral LPS infusion induced distinct, time-dependent effects on each milk component. Depending on the component, effects were local, systemic, or both, suggesting involvement of multiple different mediators that collectively result in systemic inhibition of milk production.

Key words: milk composition, lipopolysaccharide, acute response, mastitis, inflammation

\section{INTRODUCTION}

In dairy cows, acute coliform mastitis remains an obstacle to efficient milk production, premium milk quality, and animal health. Infection by coliforms, particularly Escherichia coli, often leads to the rapid onset of clinical symptoms and altered production in infected quarters, comprising hypogalactia, elevated SCC, and reduced milk components (Burvenich et al., 2003). Mastitis places a financial and managerial burden on producers, who must absorb the costs of lost milk production while making swift and appropriate decisions to prevent further losses and restore cow health. To aid decision making, research involving experimentally induced mastitis has greatly expanded knowledge of the disease, whether through infection by live bacteria (Hoeben et al., 2000; Mitterhuemer et al., 2010) or infusion of bacterial-derived, proinflammatory LPS (Guidry et al., 1983; Shuster et al., 1991a). Similar to severe cases of mastitis, LPS infusion affects not only the infused glands but also the uninfused adjacent glands, termed the systemic effect (Shuster et al., 1991a; Hoeben et al., 2000). However, due to the complex pathophysiology of mastitis, the cause of these systemic responses remains incompletely understood.

Each quarter of a bovine udder is an anatomically independent, functionally distinct gland. Generally, after unilateral experimental infusion, bacteria can be 
isolated only from the milk of infused quarters while cultures from neighboring quarters remain negative (Mitterhuemer et al., 2010), illustrating that milk and bacteria are unable to cross from one gland into another. For this reason, many studies have used individual quarters or udder halves as separate experimental units to compare treatments within cow (Bouchard et al., 1999; Persson Waller et al., 2003; Schmitz et al., 2004). However, when one gland is infused with LPS, the endotoxin itself, along with several proinflammatory molecules, can escape into blood (Ziv et al., 1976) and lymph (Persson Waller et al., 2003). Supporting this evidence of systemic inflammatory mediators, several studies have argued against quarter independence, noting increased SCC (Schultze and Bramley, 1982), altered milk composition (Paixão et al., 2017), and differentially expressed genes (Mitterhuemer et al., 2010) in adjacent glands, which were previously presumed unaffected.

Several milk components, including fat, protein, and lactose, are known to change depending on quarter health status (Bruckmaier et al., 2004; Nielsen et al., 2005) or in response to LPS. Additionally, most responses to an LPS challenge occur within the first 24 h (Guidry et al., 1983; Shuster et al., 1991a). However, despite the rapid onset of clinical symptoms, few studies have included measurement of milk components at intervals earlier than $12 \mathrm{~h}$ post-challenge. Experiments that included sampling earlier and more frequently than $12 \mathrm{~h}$ have focused mainly on immune responses (Shuster et al., 1993; Bouchard et al., 1999; Persson Waller et al., 2003), although 2 included measurement of proteins (Wellnitz et al., 2015) and lactose (Guidry et al.,1983). To our knowledge, $6 \mathrm{~h}$ post-LPS infusion is the earliest time point at which milk composition has been examined, and results indicated that different milk components are regulated independently at this time (Shuster et al., 1991a). Thus, acute changes in milk composition provoked by an LPS challenge are worth investigating to understand local and systemic effects.

Our long-term goal is to identify mechanisms causing the acute local and systemic reactions of mammary glands to intramammary LPS. In the present experiment, we designed a unilateral challenge model with sample collection at 3 and $6 \mathrm{~h}$ post-infusion to capture relatively early temporal responses. Our objectives were to determine if and when each milk component responded to local or systemic effects over an acute time course so that relationships between components and potential mediators could be identified. Further, we tested several previous hypotheses proposed to explain the systemic changes in lactation.

\section{MATERIALS AND METHODS}

All procedures involving animals were approved by the University of Missouri Institutional Animal Care and Use Committee (protocol no. 9283).

\section{Animals and Management}

Ten multiparous Holstein-Friesian $(\mathrm{n}=8)$ or Jersey $\times$ Holstein $(n=2)$ cows were paired by breed, udderlevel SCC, and daily milk yield. All cows included in the study had cow-level SCC $<174,000$ cells $/ \mathrm{mL}$ based on the most recent monthly DHIA testing (Mid-South Dairy Records, Springfield, MO), and all had reached mid lactation (range: 157-373 DIM) except one (75 DIM). All quarters of eligible cows were aseptically sampled at d -14 and -8 before infusions, and all quarters of enrolled cows were culture-negative for major mastitis pathogens.

Cows were moved from freestall housing and temporarily housed in a straw-bedded pack barn. Cows had free access to water and were fed ad libitum a TMR formulated to meet or exceed lactational requirements. All cows were milked twice daily before and during the experiment. For 2 mornings before initiation of the experiment, cows were milked in a portable chute to familiarize each cow with the novel routine.

\section{Design}

Paired cows were randomly assigned to 1 of 2 cowlevel treatments: LPS $(\mathbf{T})$ or control $(\mathbf{C})$. Within the respective treatment, udder halves were assigned 1 of 2 subtreatments (Figure 1). For T cows, the left or right udder half was randomly assigned to receive an infusion of $50 \mu \mathrm{g}$ of E. coli LPS (serotype O55:B5; SigmaAldrich, St. Louis, MO) in $10 \mathrm{~mL}$ of $0.9 \%$ sterile saline into both of the ipsilateral front and rear quarters (designated T-L). The contralateral quarters received only $10 \mathrm{~mL}$ of sterile saline (designated T-S). For C cows, ipsilateral quarters of one udder half received infusions of $10 \mathrm{~mL}$ of saline (designated $\mathbf{C - S}$ ), whereas the contralateral quarters were not infused (designated C-N). All quarters of each cow were infused within 1 min, defined as $0 \mathrm{~h}$.

Cows were quarter milked at 12 -h intervals relative to infusions. Individual quarter milk samples were collected from front quarters at milkings and at 3 and $6 \mathrm{~h}$ post-infusions. Rectal temperature and blood samples were collected at milk sampling times. As part of another study, cows were sedated and both rear quarters were biopsied at 0,3 , and $12 \mathrm{~h}$ post-infusions. Biopsies compromised the blood-milk barrier, thus precluding 
meaningful measurement of milk components in blood as indicators of inflammation. Accordingly, milk yield and composition were determined from the nonbiopsied front quarters.

At the morning milking on the initial day of the experiment, cows were randomly assigned a milking order. After milking, cows were restrained in a stationary stanchion and sedated by intravenous injection of 20 to $30 \mu \mathrm{g}$ of xylazine (Akorn Inc., Lake Forest, IL)/kg of BW in preparation to obtain mammary biopsies from both rear quarters, following the method of Farr et al. (1996). Immediately after biopsy, quarters were aseptically infused with LPS or saline or remained uninfused according to the experimental design described above. All cows were infused approximately 49 min after milking (range: 30-90 min). After infusion, teat ends were held closed and the udder was massaged for $10 \mathrm{~s}$ to distribute solutions. Cows were released back to the pack barn with free access to TMR and water until the next sampling time.

\section{Milking and Milk Sampling}

For milk sampling ( -24 and $-1 \mathrm{~h}$ pre-infusion; 3,6 , 12 , and $24 \mathrm{~h}$ post-infusion), teats were dipped in iodine, manually stripped 2 to 3 times, and thoroughly dried with a clean paper towel. Then, 25 to $30 \mathrm{~mL}$ of foremilk was manually expressed into a container and preserved with a bronopol tablet for DHI analysis. Immediately thereafter, an additional 80 to $90 \mathrm{~mL}$ was collected into two 50-mL conical tubes. When sampling coincided with
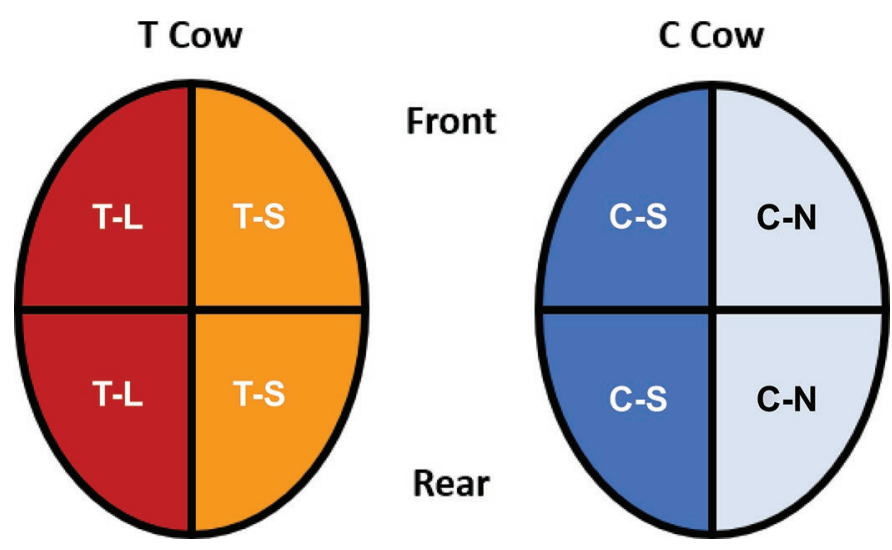

Figure 1. Experimental design. Cows were paired (see Materials and Methods), and one cow of each pair was randomly assigned to receive intramammary infusions of LPS in both quarters of one udder half. These cows were designated $\mathrm{T}$ to indicate LPS treatment. Quarters of T cows that were infused with LPS $(50 \mu \mathrm{g}$ in $10 \mathrm{~mL}$ of saline) were designated T-L, and their contralateral quarters, which received $10 \mathrm{~mL}$ of saline, were designated T-S. The other cow of each pair was designated the control (C). Udder halves of $\mathrm{C}$ cows received either infusions of $10 \mathrm{~mL}$ of saline (designated C-S) or no infusions (designated C-N). milking times ( -24 and $-1 \mathrm{~h}$ pre-infusion; 12 and 24 $\mathrm{h}$ post-infusion), the quarter milking unit was attached immediately after foremilk collection and the remaining milk was harvested by portable machine milking into collapsible bottles corresponding to each quarter. Cows were milked out with 10 to 20 IU of oxytocin given intravenously after unit attachment. After milking, each milk bottle was weighed to obtain milk yields per quarter and then agitated before removal of $25 \mathrm{~mL}$ of milk for DHI analysis. Thus, 2 types of quarter milk samples were collected: foremilk, representing strippings taken before machine milking, and harvested milk, defined as samples drawn from bottles after milking.

Preserved milk samples were left at ambient temperature up to 1 wk until shipment for milk composition analysis (Mid-South Dairy Records, Springfield, MO). Milk from one 50 -mL tube was centrifuged at 2,200 $\times g$ for $15 \mathrm{~min}$ at $4^{\circ} \mathrm{C}$ within 5 min of collection to separate milk fat. Then, $1-\mathrm{mL}$ aliquots of skim milk were frozen at $-20^{\circ} \mathrm{C}$ and stored at $-80^{\circ} \mathrm{C}$.

\section{Blood Sampling}

At $1 \mathrm{~h}$ pre-infusion and 3, 6, 12, and $24 \mathrm{~h}$ postinfusion, blood was taken from the coccygeal vein into vacutainer tubes (Covidien, Mansfield, MA) for serum (no additive) and plasma ( $\mathrm{K}_{3}$-EDTA). Plasma was processed within 5 min of collection, whereas serum was refrigerated overnight at $4^{\circ} \mathrm{C}$. Samples were centrifuged at $2,200 \times g$ for $15 \mathrm{~min}$ at $4^{\circ} \mathrm{C}$. Supernatants were aliquoted into $1.5-\mathrm{mL}$ tubes and stored at $-80^{\circ} \mathrm{C}$.

\section{Assays}

Milk L-lactate was measured in skim milk as described by Shapiro and Silanikove (2010) using L-lactic dehydrogenase (Sigma-Aldrich) and diaphorase (Worthington Biochemical Corp., Lakewood, NJ). Fluorescence was read at excitation/emission $=530 / 590$. Intra- and interassay coefficients of variation were 4.8 and $5.4 \%$, respectively.

Urea nitrogen concentration was analyzed in serum and skimmed foremilk samples using the colorimetric BUN procedure no. 580 (Stanbio Laboratory, Boerne, TX), which is based on acid catalyzed diacetyl monoxime methodology. Serum was analyzed directly. Milk was diluted 1:5 with the supplied acid reagent (sulfuric/ phosphoric acids) and then deproteinized by centrifugation at $17,000 \times g$ for 5 min. The clear milk-acid supernatant was then analyzed. Absorbance was read at $520 \mathrm{~nm}$. Intra- and interassay coefficients of variation were 1.8 and $2.3 \%$, respectively, for serum and 3.2 and $1.7 \%$, respectively, for milk. For validation, selected milk samples were spiked with 3 known concentrations 
of urea nitrogen and subjected to precipitation and analysis. Spike recoveries averaged $113 \pm 19 \%$ over a range of 11.5 to $26.2 \mathrm{mg} / \mathrm{dL}$.

The antioxidative potential of blood was analyzed by the ferric reducing ability of plasma (FRAP) assay adapted from Benzie and Strain (1996). Working FRAP reagent was freshly prepared and plasma was diluted 1:2 with double-distilled water. Forty microliters of the diluted plasma or standard was incubated in $200 \mu \mathrm{L}$ of FRAP reagent for 20 min before reading absorbance at $593 \mathrm{~nm}$. Known aqueous concentrations of $\mathrm{Fe}^{2+}(50-500$ $\mu M)$ were used to generate a standard curve. Intra- and interassay coefficients of variation were 4.2 and $2.4 \%$, respectively.

Plasma glucose was analyzed using PGO enzymes and $o$-dianisidine dihydrochloride (Sigma-Aldrich) according to the manufacturer's instructions. Five microliters of sample or standard was incubated in $200 \mu \mathrm{L}$ of reaction solution for $60 \mathrm{~min}$ at $37^{\circ} \mathrm{C}$ before reading absorbance at $450 \mathrm{~nm}$. A standard curve was prepared from serial dilutions of glucose with double-distilled water $(20-100 \mathrm{mg} / \mathrm{dL})$. Intra- and interassay coefficients of variation were 4.1 and $9.2 \%$, respectively. All assays were read by spectrophotometer (Synergy HT; BioTek Instruments, Winooski, VT).

\section{Statistical Analyses}

All component yields were calculated per quarter by multiplying the component percentage by the quarter milk yield. For foremilk samples, concentrations of protein and lactose were calculated as the percentage in fat-free milk according to the following equation: $[\mathrm{X} /$ $(100-\mathrm{fat})] \times 100 \%$, where $\mathrm{X}$ is the concentration of protein or lactose and fat is the fat concentration for a given sample. Covariate values for rectal temperature, milk yield, and component-related variables were then calculated as means of -24 and $0 \mathrm{~h}$. Lactate, MUN, and blood constituents were not measured at $-24 \mathrm{~h}$, and thus covariates were based on 0 -h values.

Data were analyzed for normal distributions, and outliers beyond 3 standard deviations were removed; SCC and lactate data were $\log _{10}$-transformed. Data were analyzed as a randomized complete block design in SAS 9.4 (SAS Institute Inc., Cary, NC) using PROC MIXED with repeated measures. For rectal temperature and blood constituents, the statistical model included fixed effects of treatment, time, the interaction of treatment and time, and the pre-infusion covariate, with block as the random effect. Cow within treatment was the subject for repeated measurements over time. The covariance structure selected was first order autoregressive. For all milk data, the statistical model was slightly modified with quarter as the experimental unit and random effects of cow over time within block. The covariance structure selected was compound symmetry. For variables with missing data, degrees of freedom were calculated using the Kenward-Roger approximation method. When main effects or interactions were significant, differences between means were determined using the PDIFF option. Covariate-adjusted least squares means and standard errors of the means are reported. Significance was declared at $P<0.05$.

\section{RESULTS}

By $3 \mathrm{~h}$ post-infusion, $\mathrm{T}$ cows developed hyperthermia $(P<0.01)$, which persisted for at least $3 \mathrm{~h}$ and had resolved by $12 \mathrm{~h}$ (Figure 2). The following morning (24 $\mathrm{h}), \mathrm{T}$ cows had lower rectal temperatures compared with $\mathrm{C}$ cows $(P<0.05)$. Temperatures in $\mathrm{C}$ cows remained stable over the duration of the experiment.

\section{Milk Production}

Before infusions, quarter-level milk yield did not differ between cow treatment groups (T vs. C; $P>0.25$ ) or udder halves $(P=0.12)$. Individual front quarter milk yield (12-h interval) for all treatments averaged $3.14 \pm 0.27 \mathrm{~kg} /$ quarter at $0 \mathrm{~h}$. To assess potential effects of saline infusion on mammary function, we compared C quarters, C-S and C-N. Overall milk yield in $\mathrm{C}-\mathrm{N}$ was lower than in C-S (Table 1) because yields were numerically lower throughout the experiment and significantly lower $(P=0.03)$ at $12 \mathrm{~h}$.

Overall milk yield was lower in $\mathrm{T}$ cows than in $\mathrm{C}$ cows (Table $1 ; P<0.05$ ). At $12 \mathrm{~h}$, milk yields of T-L and T-S

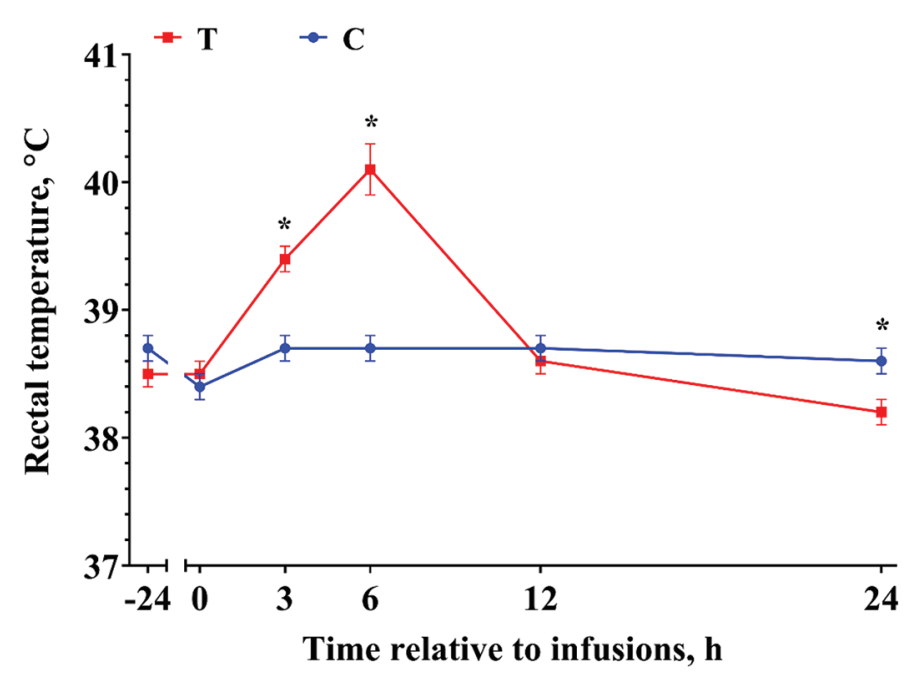

Figure 2. Rectal temperature relative to LPS infusion in treated $(\mathrm{T})$ or control $(\mathrm{C})$ cows. Values are $\mathrm{LSM} \pm \mathrm{SEM}$. Treatment $\times$ time effect, $P<0.001$. * Means within time differ significantly $(P<0.05)$. 
quarters were lower than their pre-infusion yields $(P=$ 0.04 ) but not different from yields of $\mathrm{C}$ quarters (Figure 3). By $24 \mathrm{~h}$, yields of T-L and T-S quarters were less than yields of $\mathrm{C}$ quarters (Figure $3 ; P<0.001$ ).

\section{Harvested Milk}

Samples were obtained from machine milkings at normal 12-h intervals. By $12 \mathrm{~h}$ post-infusion, milk somatic cell concentration was substantially higher in T-L compared with T-S and $\mathrm{C}$ quarters $(P<0.001)$ and remained elevated at $24 \mathrm{~h}$, with most samples from T-L quarters exceeding the maximum detection limit of 10 million cells $/ \mathrm{mL}$. On the other hand, there was no difference between quarters in fat, total protein, or lactose concentration of milk obtained at these milkings (Table 1).

Yield of somatic cells was higher in T-L than in T-S and $\mathrm{C}$ quarters at $12-$ and 24 -h milkings $(P<0.001)$, but yield of T-S quarters did not differ from that of $\mathrm{C}$ quarters until $24 \mathrm{~h}$, when T-S yield was lower (Table $1 ; P=0.01$ ). Compared with $12 \mathrm{~h}$, both T-L and T-S quarters yielded fewer cells at $24 \mathrm{~h}$, concomitant with the further decline in milk yield. In comparison, all yields of fat, protein, and lactose in both T-L and T-S declined over time, becoming significantly different from both $\mathrm{C}$ quarters at $24 \mathrm{~h}$ (Table $1 ; P<0.01$ ).

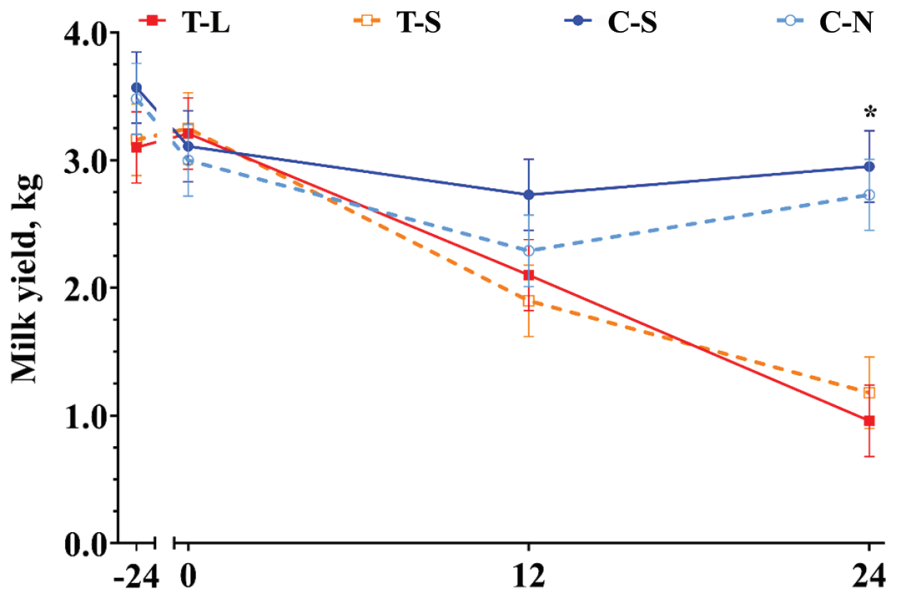

Time relative to infusions, $h$

Figure 3. Front quarter milk production at milkings relative to treatment: control, no infusion $(\mathrm{C}-\mathrm{N})$ or saline $(\mathrm{C}-\mathrm{S})$; treated, $50 \mu \mathrm{g}$ of LPS (T-L) or saline (T-S). Values are LSM \pm SEM. Treatment effect, $P<0.01$. *Means within time differ significantly between cow treatment $(P<0.05)$.

\section{Foremilk Components}

Somatic Cells. The SCC increased more than 30fold in LPS-treated quarters by $6 \mathrm{~h}$ (Figure 4A). At 3 $\mathrm{h}, \mathrm{SCC}$ in foremilk increased in all quarters except T-S $(P<0.01)$, before $\mathrm{C}$ quarters began to return to pre-

Table 1. Effects of intramammary LPS, saline, or no infusion on milk components from harvested samples at 12 and $24 \mathrm{~h}^{1}$

\begin{tabular}{|c|c|c|c|c|c|c|c|c|c|}
\hline \multirow[b]{2}{*}{ Item $^{2}$} & \multirow[b]{2}{*}{ Time, h } & \multicolumn{4}{|c|}{ Treatment $^{3}$} & \multirow{2}{*}{$\begin{array}{c}\text { Pooled } \\
\text { SEM }\end{array}$} & \multicolumn{3}{|c|}{$P$-value } \\
\hline & & $\mathrm{T}-\mathrm{L}$ & $\mathrm{T}-\mathrm{S}$ & C-S & $\mathrm{C}-\mathrm{N}$ & & Treatment & Time & Treatment $\times$ time \\
\hline Milk, kg & $\begin{array}{l}12 \\
24\end{array}$ & $\begin{array}{l}2.10^{\mathrm{b}} \\
0.96^{\mathrm{b}}\end{array}$ & $\begin{array}{l}1.90^{\mathrm{b}} \\
1.18^{\mathrm{b}}\end{array}$ & $\begin{array}{l}2.74^{\mathrm{a}} \\
2.95^{\mathrm{a}}\end{array}$ & $\begin{array}{l}2.29^{\mathrm{b}} \\
2.73^{\mathrm{a}}\end{array}$ & 0.28 & 0.004 & $<0.001$ & 0.06 \\
\hline \multicolumn{10}{|l|}{ Yield } \\
\hline Fat, g & $\begin{array}{l}12 \\
24\end{array}$ & $\begin{array}{l}85.5^{\mathrm{b}} \\
36.1^{\mathrm{b}}\end{array}$ & $\begin{array}{l}81.4 \\
45.0^{\mathrm{b}}\end{array}$ & $\begin{array}{l}113.1 \\
108.3^{\mathrm{a}}\end{array}$ & $\begin{array}{c}98.5 \\
106.7^{\mathrm{a}}\end{array}$ & 16.0 & 0.05 & 0.07 & 0.27 \\
\hline Protein, g & $\begin{array}{l}12 \\
24\end{array}$ & $\begin{array}{l}65.7^{\mathrm{b}} \\
32.3^{\mathrm{b}}\end{array}$ & $\begin{array}{l}58.4^{\mathrm{b}} \\
43.6^{\mathrm{b}}\end{array}$ & $\begin{array}{l}86.8^{\mathrm{a}} \\
91.2^{\mathrm{a}}\end{array}$ & $\begin{array}{l}72.9^{\mathrm{b}} \\
85.5^{\mathrm{a}}\end{array}$ & 9.1 & 0.005 & $<0.001$ & 0.11 \\
\hline Lactose, $\mathrm{g}$ & $\begin{array}{l}12 \\
24\end{array}$ & $\begin{array}{l}90.4^{\mathrm{b}} \\
43.2^{\mathrm{b}}\end{array}$ & $\begin{array}{l}88.6^{\mathrm{b}} \\
51.6^{\mathrm{b}}\end{array}$ & $\begin{array}{l}127.3^{\mathrm{a}} \\
135.7^{\mathrm{a}}\end{array}$ & $\begin{array}{l}105.0^{\mathrm{b}} \\
125.4^{\mathrm{a}}\end{array}$ & 12.1 & 0.001 & $<0.001$ & 0.03 \\
\hline $\mathrm{SCC},{ }^{4}$ cells & $\begin{array}{l}12 \\
24\end{array}$ & $\begin{array}{r}10.14^{\mathrm{a}} \\
9.65^{\mathrm{a}}\end{array}$ & $\begin{array}{l}8.42^{\mathrm{b}} \\
8.16^{\mathrm{c}}\end{array}$ & $\begin{array}{l}8.45^{\mathrm{b}} \\
8.73^{\mathrm{b}}\end{array}$ & $\begin{array}{l}8.59^{\mathrm{b}} \\
8.87^{\mathrm{b}}\end{array}$ & 0.16 & $<0.001$ & 0.001 & $<0.001$ \\
\hline \multicolumn{10}{|l|}{ Concentration } \\
\hline Fat, $\%$ & $\begin{array}{l}12 \\
24\end{array}$ & $\begin{array}{l}4.45 \\
5.97\end{array}$ & $\begin{array}{l}4.73 \\
5.78\end{array}$ & $\begin{array}{l}4.03 \\
3.69\end{array}$ & $\begin{array}{l}4.01 \\
3.78\end{array}$ & 0.65 & 0.36 & 0.01 & 0.14 \\
\hline Protein, \% & $\begin{array}{l}12 \\
24\end{array}$ & $\begin{array}{l}3.20 \\
3.83\end{array}$ & $\begin{array}{l}3.14 \\
3.98\end{array}$ & $\begin{array}{l}3.25 \\
3.21\end{array}$ & $\begin{array}{l}3.22 \\
3.18\end{array}$ & 0.20 & 0.56 & 0.30 & 0.30 \\
\hline Lactose, $\%$ & $\begin{array}{l}12 \\
24\end{array}$ & $\begin{array}{l}4.34 \\
4.39\end{array}$ & $\begin{array}{l}4.65 \\
4.36\end{array}$ & $\begin{array}{l}4.63 \\
4.60\end{array}$ & $\begin{array}{l}4.60 \\
4.59\end{array}$ & 0.09 & 0.49 & 0.16 & 0.08 \\
\hline $\mathrm{SCC},{ }^{4}$ cells $/ \mathrm{mL}$ & $\begin{array}{l}12 \\
24\end{array}$ & $\begin{array}{l}6.83^{\mathrm{a}} \\
6.91^{\mathrm{a}}\end{array}$ & $\begin{array}{l}5.16^{\mathrm{b}} \\
5.32^{\mathrm{b}}\end{array}$ & $\begin{array}{l}5.04^{\mathrm{b}} \\
5.30^{\mathrm{b}}\end{array}$ & $\begin{array}{l}5.25^{\mathrm{b}} \\
5.45^{\mathrm{b}}\end{array}$ & 0.14 & $<0.001$ & $<0.001$ & $<0.001$ \\
\hline
\end{tabular}

\footnotetext{
${ }^{\mathrm{a}-\mathrm{c}}$ Covariate-adjusted LSM within a row with different superscripts differ $(P<0.05)$.

${ }^{1}$ Data are covariate-adjusted LSM \pm pooled SEM. Covariates are calculated as described in Materials and Methods.

${ }^{2}$ Per front quarter at regular machine milkings (12-h milking interval).

${ }^{3} \mathrm{~T}-\mathrm{L}=$ treated cow, LPS-infused quarter $(50 \mu \mathrm{g}$ of LPS $/ 10 \mathrm{~mL}$ of saline); T-S = treated cow, saline-infused quarter $(10 \mathrm{~mL}$ of saline); C-S = control cow, saline-infused quarter (10 $\mathrm{mL}$ of saline); $\mathrm{C}-\mathrm{N}=$ control cow, noninfused quarter.

${ }^{4} \mathrm{SCC}$ data are $\log _{10}$ transformed.
} 
infusion levels. By 6 h, SCC in T-L was higher than all other quarters $(P<0.001)$. The SCC in T-S quarters was not different from that in $\mathrm{C}$ quarters, although it was numerically higher at $12 \mathrm{~h}$.
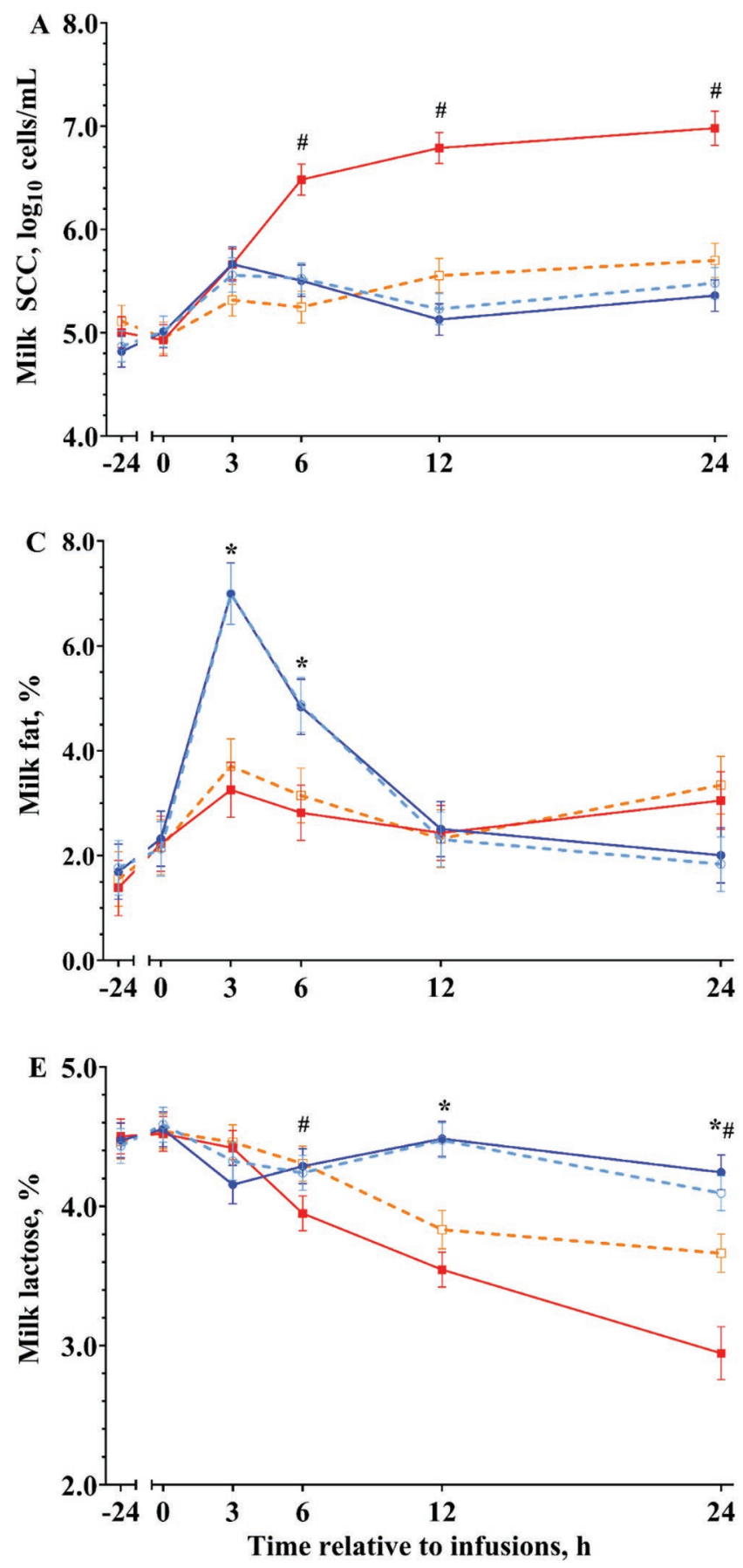

Lactate. Milk lactate concentration reflected the increased SCC in T-L quarters (Figure 4B). By $6 \mathrm{~h}$, lactate in T-L quarters increased 6 -fold from $0 \mathrm{~h}(P$ $<0.001)$. Lactate continued to increase in T-L for the
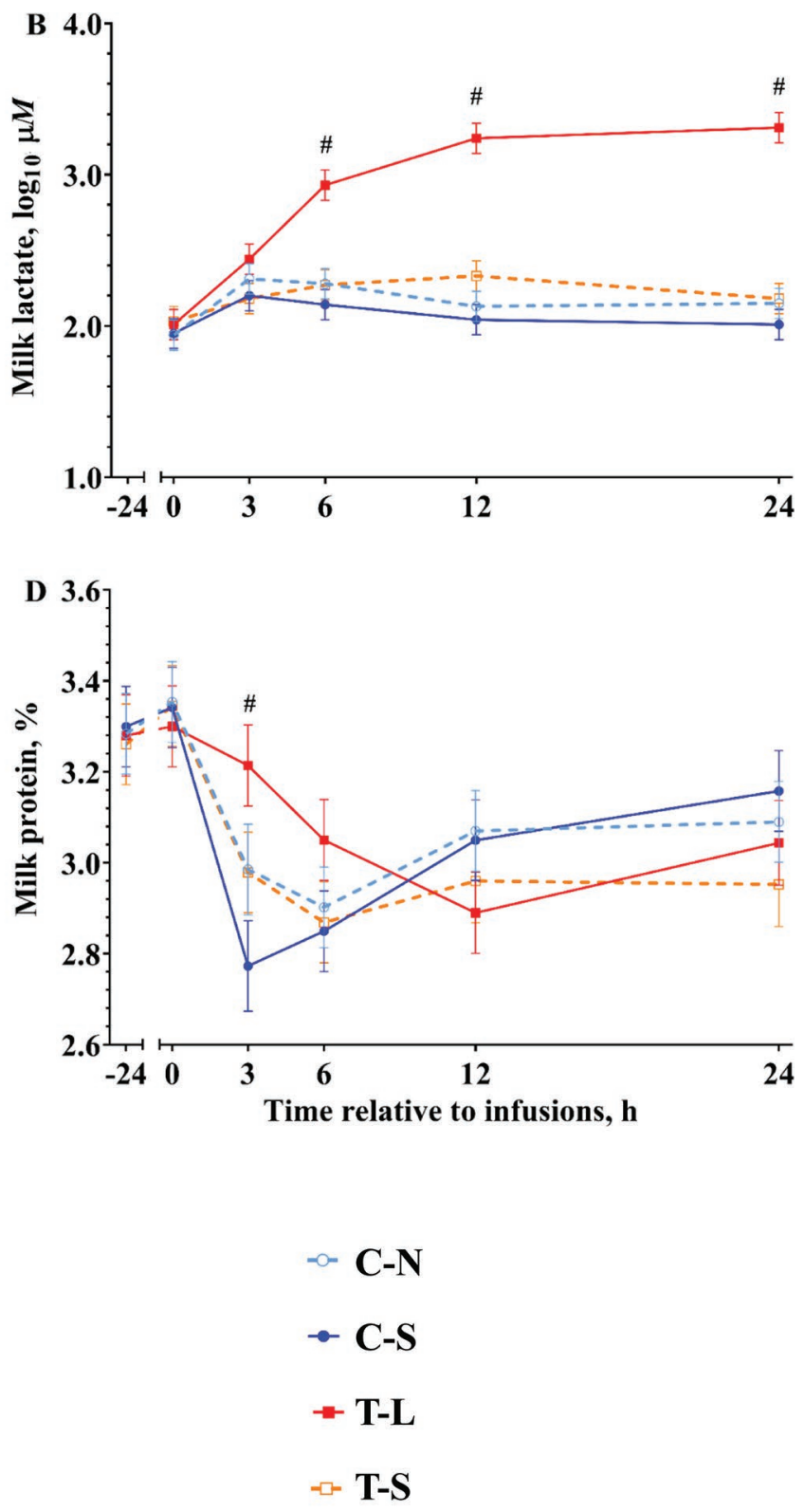

Figure 4. Foremilk concentration of (A) SCC, (B) L-lactate, (C) fat, (D) protein, and (E) lactose relative to treatment: control, no infusion $(\mathrm{C}-\mathrm{N})$ or saline $(\mathrm{C}-\mathrm{S})$; treated, $50 \mu \mathrm{g}$ of LPS (T-L) or saline (T-S). The SCC and lactate were $\log _{10}$ transformed. Values are LSM \pm SEM. Treatment $\times$ time effects, $P<0.05$. Within time, significant difference of $P<0.05$ are indicated by $*$ between cow treatment and \# between T-L and T-S. 
remainder of the experiment. Lactate concentration in T-S was not different from that in $\mathrm{C}$ quarters.

Fat. Foremilk samples had lower fat concentrations than harvested samples at $0 \mathrm{~h}(2.2 \pm 0.31 \%$ vs. $3.8 \pm$ $0.21 \% ; P<0.01)$. Unlike harvested samples, a treatment by time interaction (Figure $4 \mathrm{C} ; P=0.03$ ) in foremilk revealed treatment differences at 3 and $6 \mathrm{~h}$. Compared with $0 \mathrm{~h}$, milk from both $\mathrm{C}$ quarters had higher fat concentration at 3 and $6 \mathrm{~h}$ with roughly 3 and 2-fold increases, respectively. In contrast, the normal increase in fat concentration was almost entirely blocked in both T-L and T-S, being lower $(P<0.05)$ than that in $\mathrm{C}$ quarters at 3 and $6 \mathrm{~h}$. By $12 \mathrm{~h}$, fat concentration returned to 0 -h levels with no difference between treatments.

Protein. A treatment by time interaction $(P<0.01)$ for protein concentration indicated a transient effect on T-L quarters at $3 \mathrm{~h}$ (Figure 4D). Compared with 0 $\mathrm{h}$, all quarter treatments except T-L had lower protein concentration at $3 \mathrm{~h}(P<0.01)$, whereas T-L quarters declined more gradually and were not lower than preinfusion until $12 \mathrm{~h}$. Although there was no difference between treatments after $3 \mathrm{~h}$, treatments evoked different patterns of response in protein concentration: $\mathrm{C}$ quarters increased to near pre-infusion levels by $12 \mathrm{~h}$, T-S quarters remained unchanged from $3 \mathrm{~h}$ on, and T-L quarters decreased, reaching T-S levels by $12 \mathrm{~h}$.

Lactose. In contrast to fat and protein, lactose concentration of foremilk decreased in T-L and T-S over time to different degrees (Figure 4E). An interaction between treatment and time $(P<0.001)$ revealed distinct changes in lactose concentration within and across treatments (Figure 4E). In C quarters, lactose fell slightly between milkings $(P<0.05)$ before returning to pre-infusion levels at $12 \mathrm{~h}$. In T-L and T-S, lactose concentration fell below pre-infusion levels $(P<0.01)$ at $6 \mathrm{~h}$ in T-L quarters, preceding the decrease in T-S quarters at $12 \mathrm{~h}$. Lactose concentration from both T-L and T-S was lower than that in $\mathrm{C}$ quarters by $12 \mathrm{~h}$ $(P<0.05)$ and was further reduced by $24 \mathrm{~h}$. In addition, lactose remained lower in T-L compared with T-S quarters from $6 \mathrm{~h}$ on with the difference reaching significance at $24 \mathrm{~h}(P<0.01)$.

\section{Urea Nitrogen}

Concentrations of BUN and MUN increased over time (Figure $5 ; P<0.001$ ). Compared with pre-infusion levels, MUN increased earlier in $\mathrm{C}$ cows than in $\mathrm{T}$ cows (6 vs. $24 \mathrm{~h} ; P<0.001$ ). This followed changes in BUN concentrations, as results indicated a positive relationship between BUN and MUN $(\mathrm{r}=0.84, P<0.001)$ but no interaction between treatment and time for BUN $(P$ $=0.14)$ or MUN $(P=0.10)$. In comparing the ratio of quarter MUN to BUN, there was a time effect but not a treatment effect, with the greatest difference between milk and blood at $3 \mathrm{~h}$ post-infusions.
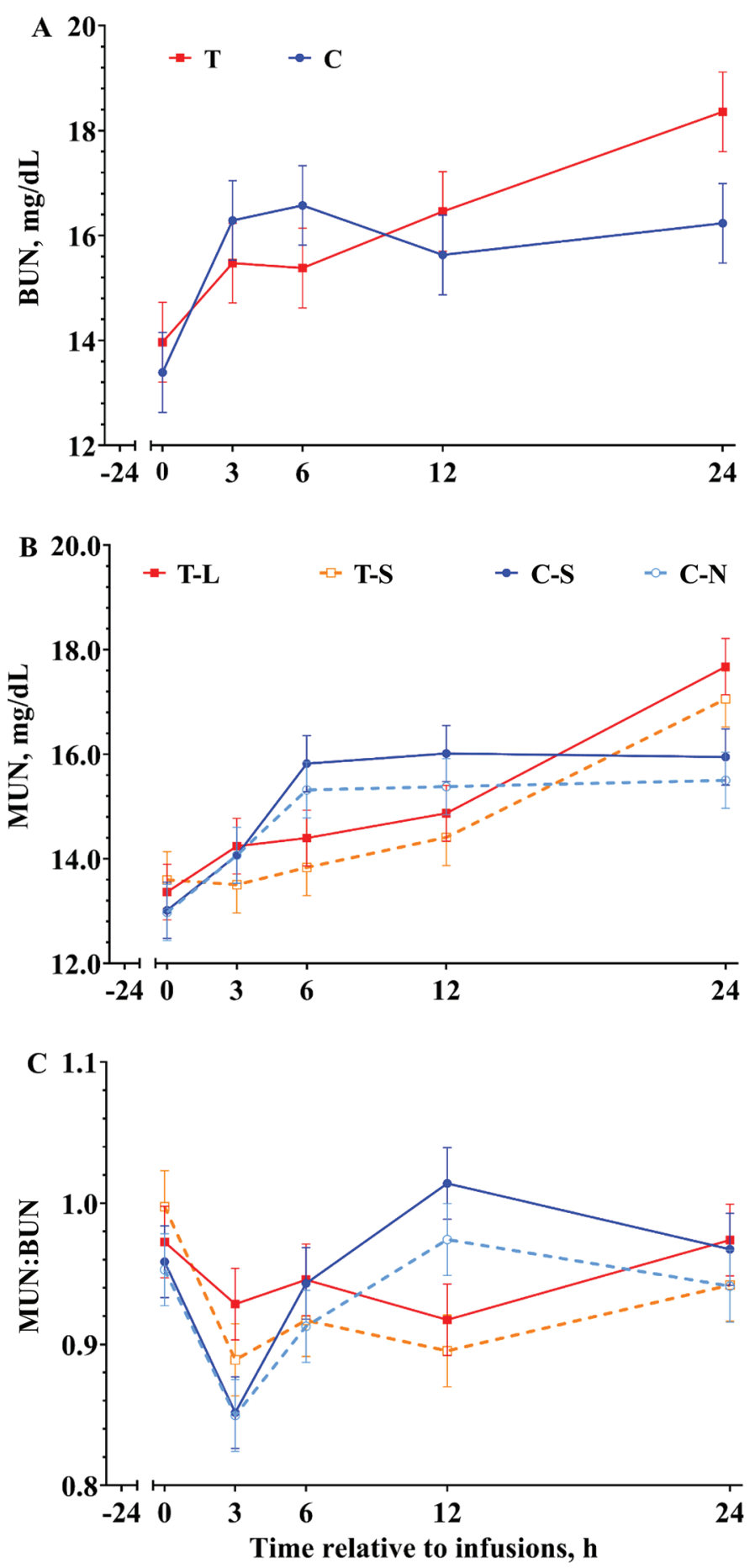

Figure 5. Urea nitrogen concentrations in (A) blood (BUN) and (B) foremilk and (C) the ratio of quarter MUN to BUN relative to LPS infusion. Cow treatment: treated $(\mathrm{T})$ or control $(\mathrm{C})$. Quarter treatment: control, no infusion (C-N) or saline (C-S); treated, $50 \mu \mathrm{g}$ of LPS $(\mathrm{T}-\mathrm{L})$ or saline $(\mathrm{T}-\mathrm{S})$. Values are LSM \pm SEM. Time effect, $P<0.01$. 


\section{Plasma Components}

Plasma glucose concentration in $\mathrm{T}$ cows was not different from that in $\mathrm{C}$ cows through $6 \mathrm{~h}$ but then declined from 6 to $12 \mathrm{~h}$ (Figure $6 \mathrm{~A} ; P<0.001$ ) before returning to pre-infusion levels by $24 \mathrm{~h}$. Likewise, the antioxidant potential of plasma was lower in $\mathrm{T}$ cows compared with $\mathrm{C}$ cows at 6 and $12 \mathrm{~h}$ (Figure $6 \mathrm{~B} ; P<$ 0.01 ) but was no longer different by $24 \mathrm{~h}$.

\section{DISCUSSION}

The collection of 2 types of milk samples, coupled with the unilateral treatments, enabled us to identify distinct local and systemic responses to LPS. Our results agreed with previous studies, wherein LPS-treated cows had significantly elevated SCC only in LPS-infused glands (Guidry et al., 1983; Shuster et al., 1991a; Mehrzad et al., 2001) but milk yield and components were depressed in both infused and noninfused quarters (Shuster et al., 1991a). Foremilk samples in particular revealed time-dependent effects of treatment on components, corroborating a prior report of lower fat and lactose concentrations at $6 \mathrm{~h}$ (Shuster et al., 1991a). Further, changes in protein concentration of milk from LPS-infused glands preceded the increase in SCC (Guidry et al., 1983; Wellnitz et al., 2015). As a first step toward identifying the underlying mechanisms, we identified several variables that were affected by local or systemic effects and improved the temporal resolution of acute responses.

Our collection of foremilk was designed to allow analysis of an acute time course while mitigating effects on 12-h milk yields. By not fully milking quarters at 3 and $6 \mathrm{~h}$, we avoided changes in composition due to frequent milk removal (Linzell, 1967) at the expense of determining yields at those times. This sampling design proved successful, as LPS treatment affected all components in foremilk. Foremilk fat and protein concentration responded the earliest, at $3 \mathrm{~h}$ post-infusion, before subsequent changes in SCC and lactose at 6 h. However, unlike protein, fat was affected not only in LPS-infused glands but also in the contralateral saline-infused glands; we refer to the effect on these saline-infused glands as the systemic response. When a component was affected only in LPS-infused glands (e.g., SCC) or affected to a greater extent in the LPSinfused glands (e.g., lactose), we refer to this as the local response.

Because fat concentration is known to be higher in hind and residual milks (Nielsen et al., 2005), milk collected between milkings was expected to have a higher fat concentration, as observed in control cows (Figure 4C). However, this normal increase appeared
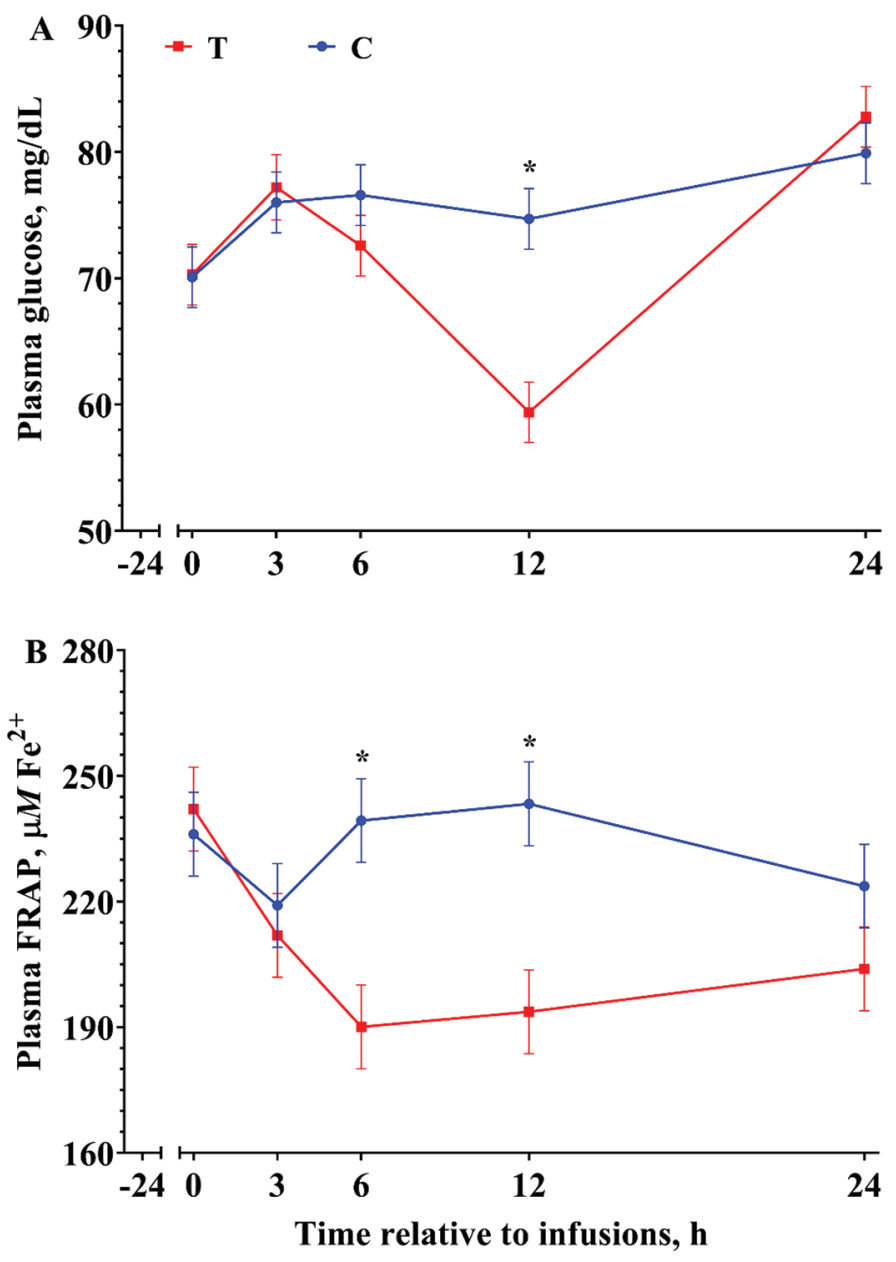

Figure 6. Plasma (A) glucose and (B) antioxidant potential (ferric reducing ability of plasma; FRAP) relative to LPS infusion in treated $(\mathrm{T})$ or control $(\mathrm{C})$ cows. Values are $\mathrm{LSM} \pm \mathrm{SEM}$. Treatment $\times$ time effects, $P<0.05$. ${ }^{*}$ Means within time differ significantly $(P<0.01)$.

to be blocked by a systemic effect. This effect must be rapid to affect cisternal milk present in the udder after milking. Further, the effect should be reversible, as fat yields rebound to pre-infusion levels sooner than protein and lactose without evidence of hypersecretion (Shuster et al., 1991a). The simplest explanation, dilution, was not supported by our data because neither protein nor lactose showed a simultaneous systemic change in concentration. We therefore suggest 3 possible mechanisms: increased lipolysis, suppressed release of milk fat globules (MFG) from the apical membrane, or stronger adhesion of MFG to each other or to the luminal epithelium. Of these, only lipolysis has been studied, though increased concentrations of free fatty acids in milk were attributed more to increased influx from blood or mechanical damage post-harvesting than catabolism of MFG (Needs and Anderson, 1984). If there is a post-secretory effect on milk fat, then the de- 
cline in fat yields over $24 \mathrm{~h}$ may not be due solely to reduced synthesis or secretion from alveoli, as previously interpreted (Shuster et al., 1991a). Given the nature of the systemic effect, further studies designed to analyze all aspects of milk fat, from synthesis to post-secretion, are warranted to understand the regulation of milk fat synthesis and secretion during mastitis.

In contrast to fat, our results suggest that protein concentration was primarily regulated by local effects. This was mainly consistent with previous findings (Guidry et al., 1983; Shuster et al., 1991a), though the latter also found systemic regulation of protein concentration. Leakage of albumin and transport of immunoglobulins across the blood-milk barrier occurs in LPS-infused glands by 2 to $4 \mathrm{~h}$ post-infusion and before the increase in SCC (Guidry et al., 1983; Wellnitz et al., 2015). However, the subsequent increased migration of polymorphonuclear neutrophils may balance protein influx with proteolysis (Mehrzad et al., 2005). These changes are consistent with our results regarding timing and pattern of changes in protein concentration relative to SCC.

Compared with fat and protein, LPS effects on lactose concentration were delayed; this was true of both local and systemic effects. As the main determinant of milk volume, lactose is the least variable component in terms of concentration. For lactose concentration to decrease, there must be an increase in other osmotically active molecules, such as electrolytes (Stelwagen et al., 1999; Bruckmaier et al., 2004). Guidry et al. (1983) reported similar local and systemic reductions in lactose concentration, which generally correlated with increased $\mathrm{Na}^{+}$and $\mathrm{Cl}^{-}$concentrations. What remains unknown is the cause of the reduced lactose, reflected in lower yields at milking. Lactose is known to leak into blood (Stelwagen et al., 1994) and be excreted in urine (Fetherston et al., 2006) when the integrity of the blood-milk barrier is compromised. On the other hand, a systemic reduction in lactose synthesis cannot be ruled out. In cultured murine mammary epithelial cells, addition of inflammatory cytokines known to respond to LPS negatively affected the lactose synthesis pathway (Kobayashi et al., 2016). Although both may explain our responses in lactose yield, this experiment was not designed to test the sources of this effect.

Milk urea nitrogen, a hydrophilic molecule known to readily equilibrate across the blood-milk barrier (Spek et al., 2016), was largely unaffected by LPS. The increase in serum urea nitrogen in all cows likely reflected changes in blood chemistry or urea metabolism, possibly due to normal diurnal variation or in response to the stress of biopsies, repeated sampling, and, in the case of treated cows, altered feed intake. The apparent delay in equilibration of MUN to BUN concentrations is in accordance with the urea flux model proposed by Spek et al. (2016), which predicts a period of $4 \mathrm{~h}$ for a difference of $3.5 \mathrm{mg} / \mathrm{dL}$ to disappear. For LPS to affect MUN, levels should equilibrate either faster or slower than predicted within the same cow. It is interesting that our results appear to show that at $3 \mathrm{~h}$, when the ratio of MUN to BUN was lowest, LPS-infused quarters had the highest ratio, suggesting faster equilibration.

Although components were initially regulated differently in response to LPS, yields of milk, lactose, protein, and fat were all systemically reduced by the first milking post-infusions. This confirms that a systemic factor(s), released into blood either from the LPS-infused gland or from nonmammary tissue, causes hypogalactia. In fact, infusing LPS intravenously also induced an overall reduction in milk yield and components without triggering an influx of leukocytes (Shuster et al., 1991b), confirming that local mammary inflammation and elevated SCC are not required to elicit this response. Some have proposed that rather than acting via post-secretory effects, such as leakage through the blood-milk barrier or destruction of components, this systemic factor reduces the synthetic or metabolic capacity of the gland (Shuster et al., 1991a; Silanikove et al., 2011; Kvidera et al., 2017). We therefore chose 3 theories to test.

We measured antioxidant potential by FRAP to determine whether systemic oxidative stress could reduce the synthetic capacity of the mammary gland. Oxidative stress results from an excess of reactive oxygen species (ROS) relative to antioxidants and has been associated with cellular and lipid damage (Sordillo and Aitken, 2009). Mehrzad et al. (2001) reported that PMN generate more ROS in the first $12 \mathrm{~h}$ following activation by LPS, which coincides with our finding of lower antioxidant potential from 6 to $12 \mathrm{~h}$ post-LPS infusion (Figure 6B) while SCC was elevated locally. Although FRAP alone cannot confirm oxidative stress, intramammary LPS might cause the release of ROS into circulation before systemic effects on mammary function.

Another proposed cause of hypogalactia is a limited availability of milk precursors, particularly glucose. Although our transient decrease in blood glucose concentration agrees with Waldron et al. (2003) and may explain lower milk yields at $12 \mathrm{~h}$, it did not correlate with changes in composition or the lowest yields at 24 h. Moreover, Kvidera et al. (2017) reported that infusing glucose to maintain euglycemia did not rescue milk production in an LPS-infusion study, casting doubt on blood glucose concentration controlling milk synthesis. Instead, this could imply a lower mammary extraction 
of glucose from blood, which would explain why glucose concentrations had returned to normal at the time of most severe hypogalactia.

Rather than nutrient availability or extraction directly limiting production, Silanikove et al. (2011) proposed that the mammary gland switches to glycolysis during mastitis, thereby utilizing less energy for milk production and conserving glucose for immune function. They theorized that increasing levels of L-lactate in milk indicated that mammary epithelial cells had shifted to glycolytic metabolism (Silanikove et al., 2011). However, we observed an increase in lactate only in milk from LPS-infused glands despite the systemic reduction in milk production and component synthesis, so this theory clearly cannot account for systemic effects. Furthermore, increased milk lactate concentrations have been associated with elevated SCC (Davis et al., 2004), presumably because neutrophils rely on glycolysis for energy metabolism and generate lactate as the end product (Borregaard and Herlin, 1982). Thus, although we cannot exclude the possibility that epithelial cells undergo altered metabolism during mastitis, our milk lactate results do not support a switch to glycolysis.

Several previous studies and lines of evidence suggested that cytokines elicited by LPS could function as mediators of local and systemic effects (Shuster et al., 1993; Persson Waller et al., 2003; Vernay et al., 2012). Indeed, the changes we and others observed in milk yield and components coincide with or follow changes in the expression and concentrations of various cytokines. Leukocyte-recruiting interleukins (IL-1, 6, and 8) can increase markedly in challenged glands by $2 \mathrm{~h}$ (Shuster et al., 1993; Persson Waller et al., 2003) which may explain the subsequent local increase in SCC. Different cytokines also cause different effects. For example, lactose synthesis-related genes may be strongly downregulated by one cytokine but differentially regulated by another (Kobayashi et al., 2016). Cytokines are also not limited to local quarters because as concentrations of IL-8 in milk increased, a small but simultaneous increase occurred in both afferent and efferent lymph (Persson Waller et al., 2003), potentially affecting neighboring quarters. Our results show that each major milk component responded distinctly, in terms of local, systemic, and temporal effects, implying the action of a single mediator on different pathways, differences in sensitivity between pathways, or, most likely, multiple mediators that act uniquely on milk components but collectively cause an overall reduction in milk yield.

\section{CONCLUSIONS}

All major milk components were regulated uniquely, responding to local or systemic effects within the first
$12 \mathrm{~h}$ after unilateral LPS infusion. Changes in milk fat concentration were the first indication of systemic effects, which occurred within $3 \mathrm{~h}$ of LPS infusion. Changes in antioxidant capacity, plasma glucose, and lactate did not account for the systemic suppression of mammary function. We conclude that different mediators exert unique effects on milk components during the acute response to LPS.

\section{ACKNOWLEDGMENTS}

Authors ES, RR, RC, FQZ, and TM designed the research; ES, RR, MW, RC, and TM performed the research; ES, RR, and TM analyzed the data; and ES and TM wrote the manuscript. We thank John Denbigh and the staff at Foremost Dairy Research Center (Columbia, MO) for providing animals and assisting with animal care. This study was partly funded by Agriculture and Food Research Initiative Competitive Grant no. 2016-09363 from the USDA National Institute of Food and Agriculture (Washington, DC) to FQZ. The authors certify that there is no conflict of interest.

\section{REFERENCES}

Benzie, I. F. F., and J. J. Strain. 1996. The ferric reducing ability of plasma (FRAP) as a measure of "antioxidant power": The FRAP assay. Anal. Biochem. 239:70-76. https://doi.org/10.1006/abio .1996 .0292 .

Borregaard, N., and T. Herlin. 1982. Energy metabolism of human neutrophils during phagocytosis. J. Clin. Invest. 70:550-557. https: //doi.org/10.1172/jci110647.

Bouchard, L., S. Blais, C. Desrosiers, X. Zhao, and P. Lacasse. 1999. Nitric oxide production during endotoxin-induced mastitis in the cow. J. Dairy Sci. 82:2574-2581. https://doi.org/10.3168/jds .S0022-0302(99)75512-8.

Bruckmaier, R. M., C. E. Ontsouka, and J. W. Blum. 2004. Fractionized milk composition in dairy cows with subclinical mastitis. Vet. Med. (Praha) 49:283-290. https://doi.org/10.17221/5706 -VETMED.

Burvenich, C., V. Van Merris, J. Mehrzad, A. Diez-Fraile, and L. Duchateau. 2003. Severity of E. coli mastitis is mainly determined by cow factors. Vet. Res. 34:521-564. https://doi.org/10.1051/vetres: 2003023.

Davis, S. R., V. Farr, C. Prosser, G. Nicholas, S. Turner, J. Lee, and A. Hart. 2004. Milk L-lactate concentration is increased during mastitis. J. Dairy Res. 71:175-181. https://doi.org/10.1017/ S002202990400007x.

Farr, V. C., K. Stelwagen, L. R. Cate, A. J. Molenaar, T. B. McFadden, and S. R. Davis. 1996. An improved method for the routine biopsy of bovine mammary tissue. J. Dairy Sci. 79:543-549. https: //doi.org/10.3168/jds.S0022-0302(96)76398-1.

Fetherston, C. M., C. T. Lai, L. R. Mitoulas, and P. E. Hartmann. 2006. Excretion of lactose in urine as a measure of increased permeability of the lactating breast during inflammation. Acta Obstet. Gynecol. Scand. 85:20-25. https://doi.org/10.1080/ 00016340500324514.

Guidry, A. J., M. Ost, I. H. Mather, W. E. Shainline, and B. T. Weinland. 1983. Sequential response of milk leukocytes, albumin, immunoglobulins, monovalent ions, citrate, and lactose in cows given infusions of Escherichia coli endotoxin into the mammary gland. Am. J. Vet. Res. 44:2262-2267. 
Hoeben, D., C. Burvenich, E. Trevisi, G. Bertoni, J. Hamann, R. Bruckmaier, and J. Blum. 2000. Role of endotoxin and TNF- $\alpha$ in the pathogenesis of experimentally induced coliform mastitis in periparturient cows. J. Dairy Res. 67:503-514. https://doi.org/10 $.1017 / \mathrm{s} 0022029900004489$.

Kobayashi, K., C. Kuki, S. Oyama, and H. Kumura. 2016. Pro-inflammatory cytokine TNF- $\alpha$ is a key inhibitory factor for lactose synthesis pathway in lactating mammary epithelial cells. Exp. Cell Res. 340:295-304. https://doi.org/10.1016/j.yexcr.2015.10.030.

Kvidera, S. K., E. A. Horst, M. Abuajamieh, E. J. Mayorga, M. V. S. Fernandez, and L. H. Baumgard. 2017. Glucose requirements of an activated immune system in lactating Holstein cows. J. Dairy Sci. 100:2360-2374. https://doi.org/10.3168/jds.2016-12001.

Linzell, J. L. 1967. The effect of very frequent milking and of oxytocin on the yield and composition of milk in fed and fasted goats. J. Physiol. 190:333-346. https://doi.org/10.1113/jphysiol.1967 .sp008212.

Mehrzad, J., C. Desrosiers, K. Lauzon, G. Robitaille, X. Zhao, and P. Lacasse. 2005. Proteases involved in mammary tissue damage during endotoxin-induced mastitis in dairy cows. J. Dairy Sci. 88:211-222. https://doi.org/10.3168/jds.S0022-0302(05)72679-5.

Mehrzad, J., H. Dosogne, E. Meyer, and C. Burvenich. 2001. Local and systemic effects of endotoxin mastitis on the chemiluminescence of milk and blood neutrophils in dairy cows. Vet. Res. 32:131-144. https://doi.org/10.1051/vetres:2001100.

Mitterhuemer, S., W. Petzl, S. Krebs, D. Mehne, A. Klanner, E. Wolf, H. Zerbe, and H. Blum. 2010. Escherichia coli infection induces distinct local and systemic transcriptome responses in the mammary gland. BMC Genomics 11:138. https://doi.org/10.1186/1471 -2164-11-138.

Needs, E. C., and M. Anderson. 1984. Lipid composition of milks from cows with experimentally induced mastitis. J. Dairy Res. 51:239-249. https://doi.org/10.1017/s0022029900023505.

Nielsen, N. I., T. Larsen, M. Bjerring, and K. L. Ingvartsen. 2005. Quarter health, milking interval, and sampling time during milking affect the concentration of milk constituents. J. Dairy Sci. 88:3186-3200. https://doi.org/10.3168/jds.S0022-0302(05)73002 -2 .

Paixão, M. G., L. R. Abreu, R. Richert, and P. L. Ruegg. 2017. Milk composition and health status from mammary gland quarters adjacent to glands affected with naturally occurring clinical mastitis. J. Dairy Sci. 100:7522-7533. https://doi.org/10.3168/jds.2017 -12547 .

Persson Waller, K., I. G. Colditz, S. Lun, and K. Östensson. 2003. Cytokines in mammary lymph and milk during endotoxin-induced bovine mastitis. Res. Vet. Sci. 74:31-36. https://doi.org/10.1016/ s0034-5288(02)00147-9.

Schmitz, S., M. W. Pfaffl, H. H. D. Meyer, and R. M. Bruckmaier. 2004. Short-term changes of mRNA expression of various inflammatory factors and milk proteins in mammary tissue during LPSinduced mastitis. Domest. Anim. Endocrinol. 26:111-126. https:// doi.org/10.1016/j.domaniend.2003.09.003.

Schultze, W. D., and A. J. Bramley. 1982. Effect of Escherichia coli endotoxin-mediated inflammation of one mammary quarter of the bovine udder on diapedesis into other quarters. J. Dairy Res. 49:381-385.

Shapiro, F., and N. Silanikove. 2010. Rapid and accurate determination of D- and L-lactate, lactose and galactose by enzymatic reactions coupled to formation of a fluorochromophore: Applications in food quality control. Food Chem. 119:829-833. https://doi.org/ 10.1016/j.foodchem.2009.07.029.
Shuster, D. E., R. J. Harmon, J. A. Jackson, and R. W. Hemken. 1991a. Endotoxin mastitis in cows milked four times daily. J. Dairy Sci. 74:1527-1538. https://doi.org/10.3168/jds.S0022 -0302(91)78313-6.

Shuster, D. E., R. J. Harmon, J. A. Jackson, and R. W. Hemken. 1991b. Reduced lactational performance following intravenous endotoxin administration to dairy cows. J. Dairy Sci. 74:3407-3411. https://doi.org/10.3168/jds.S0022-0302(91)78530-5.

Shuster, D. E., M. E. Kehrli, and M. G. Stevens. 1993. Cytokine production during endotoxin-induced mastitis in lactating dairy cows. Am. J. Vet. Res. 54:80-85.

Silanikove, N., A. Rauch-Cohen, F. Shapiro, S. Blum, A. Arieli, and G. Leitner. 2011. Lipopolysaccharide challenge of the mammary gland in bovine induced a transient glandular shift to anaerobic metabolism. J. Dairy Sci. 94:4468-4475. https://doi.org/10.3168/ jds.2010-4092.

Sordillo, L. M., and S. L. Aitken. 2009. Impact of oxidative stress on the health and immune function of dairy cattle. Vet. Immunol. Immunopathol. 128:104-109. https://doi.org/10.1016/j.vetimm.2008 .10 .305 .

Spek, J. W., J. Dijkstra, and A. Bannink. 2016. Influence of milk urea concentration on fractional urea disappearance rate from milk to blood plasma in dairy cows. J. Dairy Sci. 99:3880-3888. https:// doi.org/10.3168/jds.2015-9421.

Stelwagen, K., S. R. Davis, V. C. Farr, S. J. Eichler, and I. Politis. 1994. Effect of once daily milking and concurrent somatotropin on mammary tight junction permeability and yield of cows. J. Dairy Sci. 77:2994-3001. https://doi.org/10.3168/jds.S0022 -0302(94)77240-4.

Stelwagen, K., V. C. Farr, and H. A. McFadden. 1999. Alteration of the sodium to potassium ratio in milk and the effect on milk secretion in goats. J. Dairy Sci. 82:52-59. https://doi.org/10.3168/jds .S0022-0302(99)75208-2.

Vernay, M. C. M. B., O. Wellnitz, L. Kreipe, H. A. van Dorland, and R. M. Bruckmaier. 2012. Local and systemic response to intramammary lipopolysaccharide challenge during long-term manipulated plasma glucose and insulin concentrations in dairy cows. J. Dairy Sci. 95:2540-2549. https://doi.org/10.3168/jds.2011-5188.

Waldron, M. R., T. Nishida, B. J. Nonnecke, and T. R. Overton. 2003. Effect of lipopolysaccharide on indices of peripheral and hepatic metabolism in lactating cows. J. Dairy Sci. 86:3447-3459. https:// doi.org/10.3168/jds.S0022-0302(03)73949-6.

Wellnitz, O., C. Zbinden, J. Lüttgenau, H. Bollwein, and R. M. Bruckmaier. 2015. Different chronological patterns of appearance of blood derived milk components during mastitis indicate different mechanisms of transfer from blood into milk. J. Dairy Res. 82:322327. https://doi.org/10.1017/S0022029915000345.

Ziv, G., I. Hartman, E. Bogin, J. Abidar, and A. Saran. 1976. Endotoxin in blood and milk and enzymes in the milk of cows during experimental Escherichia coli endotoxin mastitis. Theriogenology 6:343-352. https://doi.org/10.1016/0093-691X(76)90026-1.

\section{ORCIDS}

E. M. Shangraw (ํ) https://orcid.org/0000-0001-8761-1549

R. O. Rodrigues (ํ) https://orcid.org/0000-0001-5669-3414

M. C. Witzke ๑ https://orcid.org/0000-0002-5000-2480

F.-Q. Zhao @ https://orcid.org/0000-0003-4926-670X

T. B. McFadden (1) https://orcid.org/0000-0001-5101-6844 